\title{
RESEARCH PARADIGMS FOR ACCOUNTING: A REVIEW
}

\author{
Kamisah Ismail and Suria Zainuddin
}

\begin{abstract}
This paper reviews research paradigms that have existed since the 1970s. Specifically, it reviews two frameworks by Burrell and Morgan (1979) and Chua (1986) that have become prominent as a basis for methodological stance in accounting and management research. These research paradigms or perspectives determine the research methodology applied in this study. Different schools of thought have their own views and arguments. Thus, there is no one best research method to use because every method has its own strengths and weaknesses.
\end{abstract}

Keywords Paradigm, Positivist, Interpretive and Critical

\section{Introduction}

Interest about the state and development of accounting research materialised in the 1970s. Different views on accounting paradigms have emerged and been criticised since then, including the absent role of accounting theory in organisational practice. With various approaches in empirical research to understand the nature of accounting within organisations and society, a range of schools of thought have been generated. These different accounting perspectives have led to differences in methodological approaches in accounting research. The objective of this paper is to review major paradigms that existed in accounting research, to provide accounting researchers with a better understanding of these perspectives to enable them to apply the correct methodological approach in their research.

This first part of this paper is a discussion on the frameworks by Burrell and Morgan (1979) and Chua (1986). This is then followed by a brief analysis on the different perspectives and their strengths and weaknesses.

\section{The Research Framework by Burrell and Morgan (1979)}

Among the earliest published articles on the topic of research paradigms for accounting comes from the work of Burrell and Morgan (1979). The framework described by Burrell and Morgan (1979) is depicted in Figure 1. It provides a

Corresponding author: Dr Kamisah Ismail is a Senior Lecturer at the Department of Accounting, Faculty of Business and Accountancy, University Malaya, email: kamisah.ismail@um.edu.my. Co-author: Dr. Suria Zainuddin is a Senior Lecturer at the Department of Accounting, Faculty of Business and Accountancy, University of Malaya, email: suriaz@um.edu.my. 
useful starting point in designing an abstracted classification schema to understand the broad streams of accounting or social science approaches to empirical research. In their bipolar dualism, they classified accounting literature according to two main sets of assumptions, called social science and the nature of society. Social science assumptions include a four-part schema related to ontology, epistemology, human nature and methodology. For the nature of society, it is categorised as orderly or subjected to fundamental conflict. From these two sets of assumptions, four paradigms have emerged (i.e. functionalist, interpretive, radical humanist and radical structuralist). Burrell and Morgan (1979) assumed that each paradigm was based on its own meta-theoretical assumption and it was mutually exclusive even though they could operate in different paradigms sequentially over time. Functionalist paradigm (i.e. objective-regulation) was the primary or dominant paradigm for organisational study. It was pragmatic and deeply rooted in sociological positivism. Relationships were concrete and identifiable, studied and measured via science. It assumed rational human action and believed that one could understand organisational behaviour through hypothesis testing. Interpretive paradigm (i.e. subjective-regulation) sought to explain the stability of behaviour from the individual's viewpoint. Researchers in this paradigm tried to observe "on-going processes" to better understand individual behaviour and the "spiritual nature of the world". Theorists in radical humanist paradigm (i.e. subjective-radical change) were mainly concerned with releasing social constraints that limited human potential. They saw current dominant ideologies as separating people from their "true selves". They used this paradigm to justify the desire for revolutionary change. It was largely anti-organisation in scope. In the radical structuralist paradigm (i.e. objective-radical change), theorists saw inherent structural conflicts within society as generating constant change through political and economic crises.

The Sociology of Radical Change

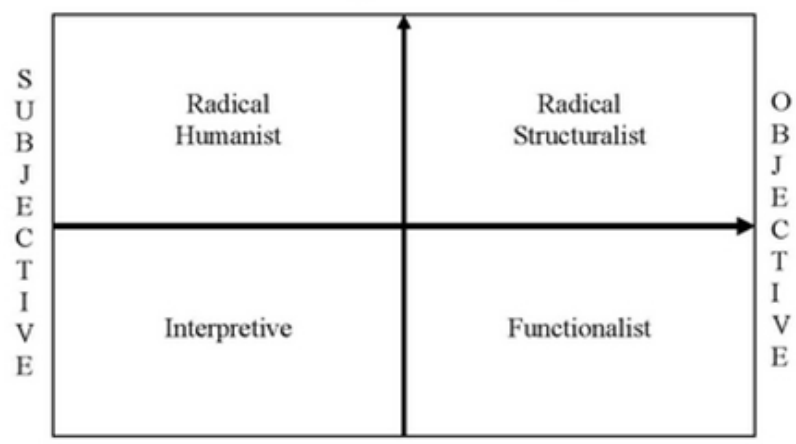

The Sociology of Regulation

Figure 1: Four paradigms for the analysis of social theory

Source: Burrell and Morgan (1979) 


\section{The Research Framework by Chua (1986)}

Table 1: The dominant assumptions of Mainstream Accounting, the Interpretative and Critical Perspectives

\begin{tabular}{|c|c|c|c|}
\hline Assumptions & Mainstream perspective & Interpretative perspective & Critical perspective \\
\hline Belief about knowledge & $\begin{array}{l}\text { Theory is separate from } \\
\text { observations that may be } \\
\text { used to verify or falsify } \\
\text { a theory. Hypothetico- } \\
\text { deductive account of } \\
\text { scientific explanation } \\
\text { accepted. Quantitative } \\
\text { methods of data analysis } \\
\text { and collection which } \\
\text { allows generalization } \\
\text { favoured. }\end{array}$ & $\begin{array}{l}\text { Scientific explanations } \\
\text { of human intention } \\
\text { sought. Their adequacy is } \\
\text { assessed via the criteria } \\
\text { of logical consistency, } \\
\text { subjective interpreta- } \\
\text { tion, and agreement with } \\
\text { actors' common-sense } \\
\text { interpretation. } \\
\text { Ethnographic work, case } \\
\text { studies and participant } \\
\text { observation encouraged. } \\
\text { Actors studied in their } \\
\text { everyday world. }\end{array}$ & $\begin{array}{l}\text { Criteria for judging } \\
\text { theories are temporal } \\
\text { and context-bound. } \\
\text { Historical, ethnographic } \\
\text { research and case studies } \\
\text { more commonly used. }\end{array}$ \\
\hline
\end{tabular}

Belief about physical and social reality
Empirical reality is objective and external to the subject. Human beings are also characterized as passive objects; not seen as makers of social reality. Single goal of utility-maximization assumed for individuals and firms. Means-end rationality assumed. Societies and organizations are essentially stable; "dysfunctional" conflict may be managed through the design of appropriate accounting control.
Social reality is emergent, Human beings have inner subjectively created, and potentialities which are objectified through human interaction.

All actions have meaning and intention that are retrospectively endowed and that are grounded in social and historical practices.

Social order assumed. Conflict mediated through common schemes of social meanings. alienated (prevented from full emergence) through restrictive mechanisms. Objects can only be understood through a study of their historical development and change within the totality of relations.

Empirical reality is characterized by objective, real relations which are transformed and reproduced through subjective interpretation.

Human intention, rationality, and agency are accepted, but this is critically analysed given a belief in false consciousness and ideology.

Fundamental conflict is endemic to society. Conflict arises because of injustice and ideology in the social, economic, and political domains which obscure the creative dimension in people.

\begin{tabular}{llll}
\hline $\begin{array}{l}\text { The relationship between } \\
\text { theory and practice }\end{array}$ & $\begin{array}{l}\text { Accounting speci- } \\
\text { fies means, not ends. } \\
\text { Acceptance of extant } \\
\text { institutional structure. }\end{array}$ & $\begin{array}{l}\text { Theory seeks only to } \\
\text { explain action and to } \\
\text { understand how social } \\
\text { order is produced and } \\
\text { reproduced. }\end{array}$ & $\begin{array}{l}\text { Theory has a critical } \\
\text { imperative: the identi- } \\
\text { fication and removal of } \\
\text { domination and ideologi- } \\
\text { cal practices. }\end{array}$ \\
\hline
\end{tabular}

Source: Chua (1986) 
While the two-by-two matrix assumed in the research by Burrell and Morgan (1979) had limitations, Chua (1986) contributed to the literature by distinguishing mainstream accounting research from alternative approaches which were known as interpretive and critical accounting research. According to Ahrens (2008), Chua (1986) dismissed the concept of the mutually exclusive paradigms of Burrell and Morgan (1979) as illogical, relativistic and superficial. In her article, Chua (1986) combined different research traditions and did not emphasise their exclusivity. By suggesting alternative approaches to mainstream accounting research, she did not aim to provide an exhaustive map of the possibilities for research. They were simply two alternatives that she found most promising. She also emphasised theoretical disagreements between researchers in all three perspectives, as shown in Table 1.

\section{Mainstream, Interpretive and Critical Accounting Research}

The idea of positivist has become the basis for mainstream accounting research today. Before the 1970s, positivist had become the unchallenged paradigm of accounting research and little discussion in its limitation had been highlighted (Lukka and Kassanen, 1995). There were a number of advantages of using the positivist research approach. Firstly, there was widespread use of large samples, which could be generalised to the whole population. Secondly, the use of survey methods, experimental laboratory research designs, and rigorous statistical methods of analysis could ensure reliable empirical evidence. Thirdly, the hallmark of good positivist research was replicability, where another researcher was able to conduct the same research in the same way and come up with comparable results. Finally, the independence between the researcher and the object being studied could be ensured total objectivity during data gathering and analysis.

The positivist approach also had several limitations and Cavana et al. (2001) have outlined four criticisms of positivist research. Firstly, they found that the positivist approach attempted to reduce all aspects of human endeavours to numbers and was thus superficial. Secondly, systems that were created out of social interactions between people failed to deal with the way people thought and felt because positivist research assumed that all people shared the same meanings. Thirdly, it claimed that the independence between the researcher and the object being studied was a myth; thus the use of statistical procedures was an attempt to hide the fact that all researchers had subjective responses and involvement with their research. Finally, statistical samples normally did not represent specific social groups, and did not allow for either illuminating generalisations or for understanding individual cases.

These limitations of mainstream research motivated Chua (1986) to explore alternative research paradigms in accounting research, called interpretative and critical accounting research. She differentiated these paradigms based on the 
assumptions about knowledge, physical and social reality, and the relationship between theory and the practical world of human affairs. The summary of the differences between the paradigms is shown in Table 1.

The interpretive approach to accounting research was gaining attention as a legitimate alternative to the mainstream accounting research (Kakkuri-Knuuttila et al., 2008; Lukka and Modell, 2010). Interpretive research was categorised as "phenomenological" because it focused on the uniqueness of an individual's thoughts and perceptions. It adopted a qualitative method such as interview or case study analysis for gaining insights into how an individual perceives a phenomenon. Interpretivism was a bottom-up, inductive approach that avoided prior assumptions.

The critical research perspective believed in humanness and the concomitant emancipation of humankind. Their aim was to empower people to create a better world for themselves. They focused on the development of new theories or the critique of existing theories and did not provide a particular method for research. It did not favour empiricism over qualitative nor vice versa, and used both deductive and inductive reasoning. Historical, ethnographic and case study research was normally used and research findings were useful to the researcher as a catalyst that led to transformation.

Even though the alternative research was growing, the mainstream accounting research had been predominant in accounting literature. Baker and Bettner (1997) demonstrated that only a small percentage of the research published in nine mainstream accounting journals in 1995 (excluding Accounting, Organizations and Society) was interpretive and critical. In management accounting discipline, Bhimani (2002) found that more than three-quarters (i.e. $77 \%$ ) of the management accounting research papers published in the European Accounting Review (EAR) were classed as from the positivist paradigm and less than a quarter (i.e. $23 \%$ ) drew on alternative paradigms. No papers adopting a critical paradigm stance were published in the EAR.

The reason for this might be due to the credibility of mainstream accounting research to produce results that could be generalised. However, the criticism that results of alternative research, especially of interpretive research, lacked generalisations was denied by Lukka and Kasanen (1995). They suggested that properly conducted case studies of high quality could also produce results that could be generalised.

Another reason for the lack of interpretive and critical research appearing in mainstream journals could be due to the restriction by editors of academic journals (Baker and Bettner, 1997). Lee (1995) asserted that at the meso-level of theory, there was a higher degree of control exercised. The alternative research papers were rarely accepted through the normal reviewing process and editors normally claimed that the research did not meet the standards of their journals (Baker and Bettner, 1997). 
Baker and Bettner (1997) listed out three reasons that hindered mainstream research from succeeding:

1. Limitations existed in fundamental assumptions underlying the research paradigms, which adversely affected their ability to provide useful understandings of social reality.

2. While attempting to comply with the strict rigour of scientific methods, mainstream research had placed emphasis on measurement for measurement's sake.

3. Research methods based on the analysis of quantitative data had been so exhaustively employed that they had reached a point of diminishing returns.

Advocates of alternative research claimed that, unlike mainstream research, they focused on the broader context of organisations and society in which accounting operated. Mainstream accounting was incapable of addressing complex social ramifications in accounting including shaping ideologies, forming political hierarchies and preserving organisational structures (Baker and Bettner, 1997). By adopting alternative research, accounting in essence could be best captured through an understanding of its impact on individuals, organisations and society.

\section{Conclusion}

In conclusion, methodological development in accounting research over the past decades have been characterised by increasing pluralism. It is important for accounting researchers to look forward to alternative research paradigms to provide different perspectives and gain new insights. Accounting researchers need to be open minded about the contributions that interpretive and critical research could make. Their research may provide different perspectives and rich insights could be gained. Although three perspectives were suggested by Chua (1986), Lee (1991) and Kakkuri-Knuuttila et al. (2008) recommended that the positivist and interpretive approaches in organisational research were mutually supportive, rather than mutually exclusive.

This paper could assist accounting researchers to understand the differences in accounting paradigms to ensure that the correct methodological approach is applied in their research.

\section{References}

Ahrens, T. (2008). Overcoming the subjective-objective divide in interpretive management accounting research. Accounting, Organizations and Society, 33, 292-297. 
Baker, C. R. and Bettner, M. S. (1997). Interpretive and critical research in accounting: a ommentary on its absence from mainstream accounting research. Critical Perspetives on Accounting, 8, 293-310.

Bhimani, A. (2002). European Management Accounting Research: Traditions in the Making. The European Accounting Review, 11(1), 99-117.

Burrell, G. and Morgan, G. (1979). Sociological paradigms and organisational analysis, Heinemann, London.

Cavana, R. Y., Delahaye, B. L. and Sekaran, U. (2001). Applied Business Research: Qualitative and Quantitative Methods, John Wiley \& Sons.

Chua, W. F. (1986). Radical developments in accounting thought. The Accounting Review, 61(4), 601-632.

Kakkuri-Knuuttila, M-L., Lukka, K. And Kuorikoski, J. (2008). Straddling between paradigms: A naturalistic philosophical case study on interpretive research in management accounting. Accounting, Organizations and Society, 33, 267-291.

Laughlin, R. (1995). Empirical research in accounting: alternative approaches and a case for "middle-range" thinking. Accounting, Auditing and Accountability Journal, 8(1), 63-87.

Lee, A. S. (1991). Integrating positivist and interpretive approaches to organizational research. Organizations Science, 2(4), 342-366.

Lukka, K. and Kasanen, E. (1995). The problem of generalizability: anecdotes and evidence in accounting research. Accounting, Auditing and Accountability Journal, 8(5), 71-90.

Lukka, K. And Modell, S. (2010). Validation in interpretive management accounting research. Accounting, Organizations and Society, 35, 462-477.

Willmott, H. (2007). Listening, interpreting, commending: A commentary on the future of interpretive accounting research. Critical Perspective Accounting. Discussion paper. 